\title{
Myelocyte Count
}

National Cancer Institute

\section{Source}

National Cancer Institute. Myelocyte Count. NCI Thesaurus. Code C74662.

The determination of the number of myelocyte cells present in a sample. 